\title{
Bifidobacterium sp as Probiotic Agent - Roles and Applications
}

\author{
Rahila Yakoob* (D) and B.V. Pradeep \\ Department of Microbiology, Karpagam Academy of Higher Education Coimbatore - 641 021, Tamilnadu, India.
}

\begin{abstract}
Probiotics are live microorganisms (mostly bacteria) that colonize the gut and supply helpful benefits. Probiotics are completely different from other varieties of microorganism in that they are considered "good" microorganism or non-pathogenic in healthy individuals. Genus Bifidobacterium is the primary microbe that colonizes human channel, and it has positive health effects on its host. Because of the acknowledged health benefits, it is included in several purposeful foods. Bifidobacteria generally occur in extremely varied ecological niches. In order to survive in these explicit ecological niches, they should be highly adaptive. This review helps researchers incorporate the utmost criteria for an acceptable probiotic strain as in the case of Bifidobacterium sp. Bifidobacteria can be considered as a probiotic and it plays an important role in anticholesterolemic, lactose intolerance, anticancerogenic, immunomodulatory effects etc.
\end{abstract}

Keywords: Probiotics, Bifidobacterium species, Beneficial microorganisms, Functional foods.

*Correspondence: rahilayakub@gmail.com

(Received: 27 July 2019; accepted: 08 September 2019)

Citation: Rahila Yakoob and B.V. Pradeep, Bifidobacterium sp as Probiotic Agent - Roles and Applications, J Pure Appl Microbiol., 2019; 13(3): 1407-1417. https://doi.org/10.22207/JPAM.13.3.11

(C) The Author(s) 2019. Open Access. This article is distributed under the terms of the Creative Commons Attribution 4.0 International License which permits unrestricted use, sharing, distribution, and reproduction in any medium, provided you give appropriate credit to the original author(s) and the source, provide a link to the Creative Commons license, and indicate if changes were made. 


\section{INTRODUCTION}

Bifidobacterium consists of about 45 species and belongs to phylum Actinobacteria. They are indigenous components of human and animal gastrointestinal micro flora. They are gram +ve, non-sporing, non-motile, rod-shaped and catalase-negative anaerobes, which produce acetic acid and lactic acids from carbohydrates without the generation of carbon-dioxide ${ }^{1}$. Genus can be distinguished from other bacterial groups like Lactobacilli, Actinomycetes and anaerobic Corynebacterium by Fructose-6-phosphate phosphoketolase (F6PPK) assay ${ }^{2,3}$.

Tissier isolated Bifidobacterium from healthy breastfed infants in the year 1899. It is also isolated from infant feces, breast milk, cow's milk, yogurts, sour cream, cheese desserts, ice cream and powdered milk ${ }^{4}$. Bifidobacteria species is predominant in the guts of breastfed infants ${ }^{5,6,7}$.

Bifidobacteria turn out medicinal drug chemicals, enzymes, vitamins $B$ and $K$ and carboxylic acid which decreases the growth of fungus, also helps in digestion and facilitates absorption of nutrients ${ }^{8,9}$. Probiotics are "live microorganisms that, once consumed in sufficient quantity, offer health benefits to their host"10.

\section{Selection criteria for probiotics}

While choosing the probiotics strain for human purpose, it ought to be isolated from the microflora that probably stick to the human intestinal wall. The strain ought to be properly isolated and known before use ${ }^{11,12,13,14}$.

There are a variety of standards to be followed throughout while choosing microorganism for probiotics. Strains of eubacterium and Bifidobacterium are usually used. Members of alternative genus like Bacillus licheniformis have conjointly been investigated to be used as probiotics ${ }^{7,15}$. Selected strains should be nonpathogenic and non-toxic. Bifidobacterium is generally considered safe ${ }^{16,7}$. Before choosing alternative probiotics, toxicologic studies should be performed ${ }^{17}$.

\section{Commercially important probiotics}

The world population have become alert to the relation between nutrition and physiological state. Probiotic cultures are exploited extensively by the dairy farm business as tools for the production of novel purposeful products. Historically probiotics are incorporated in dairy products, milk and cheese; besides milk-based probiotic products, attempts are being made to use and develop nonmilk probiotic products. A variety of carriers of probiotics have been examined recently together with edible spreads and meat. New product like cereals, fruits and vegetables are in the developmental stages ${ }^{18}$.

\section{The Beneficial effects of probiotics}

Probiotics offer familiar health benefits like prevention and amelioration of intestine diseases. They have hypocholesterolemic, anticancer and antioxidative effects. Probiotics are reported to be helpful in atopic dermatitis, wound and scar-healing, and possess skin-rejuvenating properties ${ }^{19,20}$. The major health attributes of probiotics are shown in Fig.1.

\section{Bifidobacterium}

Bifidobacterium species are one of the most abundant microbes in natural microflora of colon. The bacteria in $25 \%$ of adult feces and $80 \%$ of infant feces are Bifidobacterium ${ }^{35,36}$. Bifidobacterium species plays an important role in human health by prevention of intestinal infections, decreasing cholesterol, stimulating immune system therfor decreasing cancer risk ${ }^{34}$. The beneficial effects of Bifidobacterium sp (Table 1).

\section{Health benefits of Bifidobacterium Bifidobacteria in diarrhoea}

Many studies have reported Bifidobacteria is used to treat various gasterointestinal disorders ${ }^{21}$. This is mainly due to the administration of $B$. breve and $B$. longum. A review containing 8,014 infants, children and adult with acute diarrhea were given probiotics which contains Bifidobacterium strains, the result were found to reduce the duration

Table 1. Beneficial effects of Bifidobacterium sp

Beneficial Effects Reference

Production of vitamins: B1

(Thiamine), B7 (Biotin), B11 (Folic acid),

B12 (Cobalamine) and Riboflavin

biosynthesis.

Alleviation of lactose intolerance

$60,61,62$

Prevention and treatment of

63,64

inflammatory bowel disease

Reduction of serum cholesterol

Prevention of acute diarrhea

65

66

Prevention of colorectal cancer 
of diarrhea ${ }^{22}$. Antibiotic associated diarrhea in children and adult patients are also recommended to take probiotics along with antibiotics this have proven antibiotic donot interfere with the probiotics $^{23}$.

\section{Bifidobacteria in colorectal cancer}

Probiotics supress the growth of bacteria which convert procarcinogens into carcinogens thereby reducing the amount of carcinogens in the intestine ${ }^{17}$. Many species of Bifidobacterium have been found to reduce the incidence of tumour in the liver, colon, small intestine and mammary gland of rats ${ }^{24}$. Bacterial enzymes like $\lambda$-glucuronidase and nitroreductase play a vibrant role in the development of cancer by hydrolaysing carcinogenic compounds. Studies have reported that probiotics, including species of Bifidobacteria, decrease the activity of these enzymes thereby reducing various cancers ${ }^{25}$.

A recent study has reported that probiotic supplements containing $B$. longum and other species of Bifidobacterium, suppress the total number of colon cancer cells in rats ${ }^{26}$. Many studies have concluded that certain strains of probiotics can be used as an adjuvant in cancer treatment ${ }^{22}$.

\section{Bifidobacteria in allergic disorders}

The shift of Th1/Th2 cytokine balance towards Th2 response is associated with allergic disorders which cause the activation of Th2 cytokines and release of interleukin 4, 5 and 13 and also IgE production ${ }^{27}$. Studies have reported that long term consumption of Bifidobacterium lactis significantly reduces the allergic symptoms in children. A study evaluated the clinical and

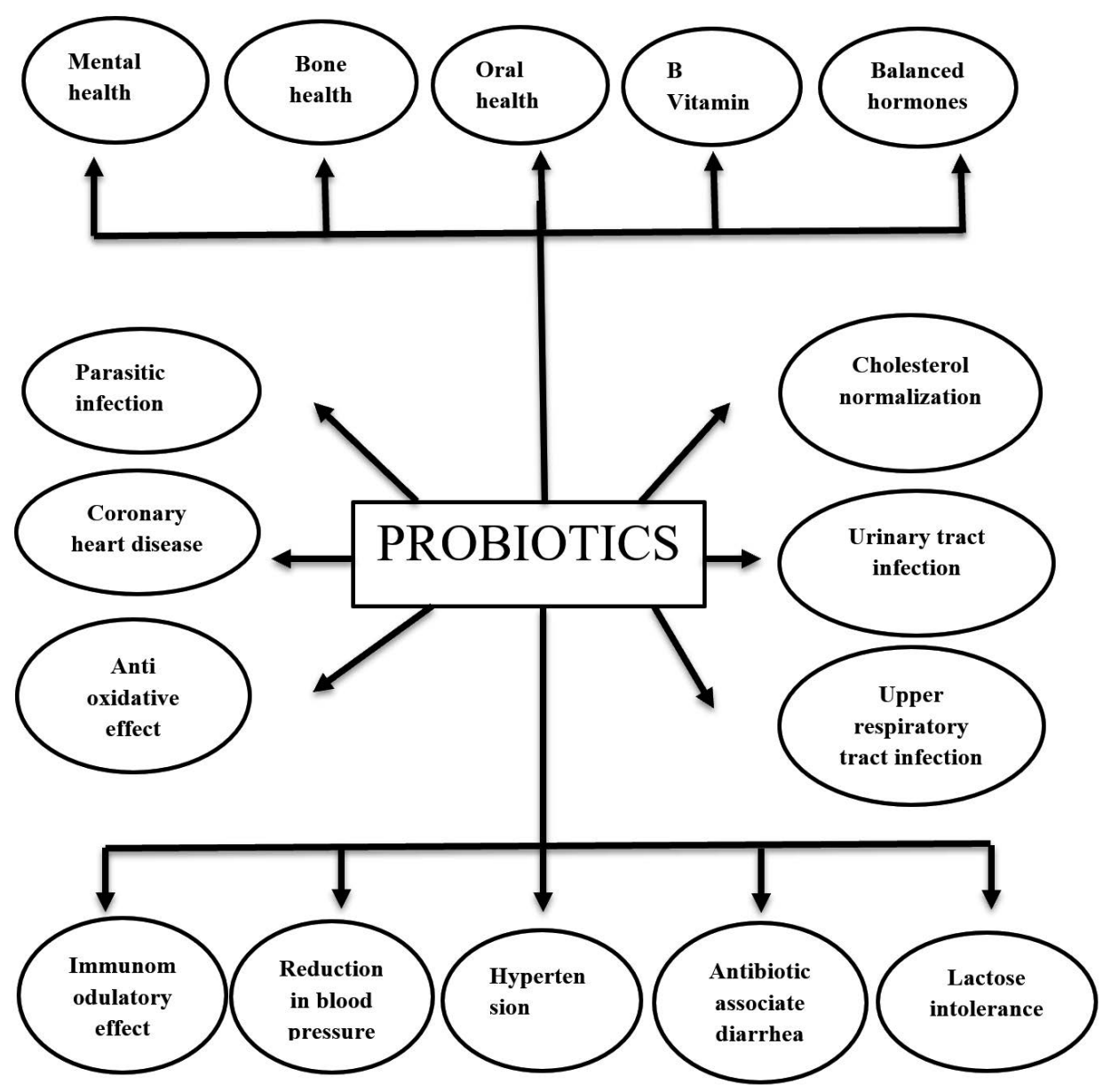

Fig. 1. Health attributes of Probiotics 
immunological changes of atopic dermatitis after consuming probiotics containing B.animalis and L.acidophilus found to play a major role in the treatment of atopic dermatitis ${ }^{28,29,30,31}$.

Bifidobacterium in Hepatic Encephalophathy Probiotics found to be effective against the treatment of hepatic encephalophathy ${ }^{32}$. Intake of different Lactobacillus and Bifidobacterium strains in an acute liver injury rat model has shown various effects on bacterial translocation and hepatocellular damage ${ }^{33}$. In another study five days of probiotic therapy with Bifidobacterium strains in alcoholic patients have significantly lowered AST and ALT activity at the end of treatment ${ }^{34}$.

\section{Characterization of Strain \\ Bile and acid tolerance}

Gastric acid and bile play a significant role in the body's defence against ingested microorganisms. In order to use bacteria as probiotics, it should be made to resist bile salts ${ }^{19}$. Bile salt plays a fundamental role in the defence mechanism of the gut.

\section{Production of antimicrobial substances}

Variety of antimicrobial substances has been produced by probiotic bacteria. Some of those compounds includes short fatty acids, bacteriocins, hydrogen peroxides etc. These have the ability to compete against gastrointestinal microbes and thereby inhibit pathogen bacteria ${ }^{37,38}$.

Bifidobacteria produce antimicrobial proteins such as bacteriocins, which are substances for the inhibition of food borne pathogens ${ }^{39}$. Bacteriocins promotes antimicrobial activity through pore formation which causes cell lysis and prevents biosynthesis of cell wall ${ }^{40}$.

\section{Adhesion properties of Bifidobacteria}

The adhesion onto mucin is used to evaluate the ability of the strains to colonise the intestine. This property is an important factor for the selection of probiotics ${ }^{41}$. Mucin in the intestine of hosts provides protection from enteric pathogens via steric hindrance specific binding for viruses and bacteria. Certain Bifidobacterium strains like $B$. bifidum, $B$. longum has afc $A$ and eng $B F$ genes which express mucin degrading glycosidase ${ }^{42}$.

\section{Carbohydrate metabolism}

Bifidobacteria are saccharolytic and play a significant role in the fermentation of carbohydrates in colon. It can also ferment different sources of carbon such as xylo-oligosaccharides. Bifidobacteria degrade hexose sugars through "bifid shunt" a metabolic pathway. In this, Fructose 6 phosphoketolase is broken down to fructose 6 phosphate in the presence of inorganic phosphate ${ }^{43}$. F6PPK assay using different chemicals like CTAB and Triton X-100 (Sigma) is a reliable test for genus identification of bifidobacteria ${ }^{35}$.

\section{Culture media for Bifidobacterium species}

Due to the non-availability of appropriate selective media, the isolation of Bifidobacterium $s p$ from various niches has been a difficult task. Several media for the enumeration of Bifidobacterium sp are tested, and Wilkins Chalgren's agar, containing $100 \mathrm{mg} / \mathrm{L}$ Mupirocin, is used as selective medium of Bifidobacterium species from milk and cheese ${ }^{44}$. Reinforced Clostridial Agar and MRS Agar containing cysteine, Columbia agar medium containing lithium chloride and sodium propionate are used as selective media in dairy products and in quality control laboratories ${ }^{45}$. MTPY medium is used for isolating Bifidobacteria from hens' gastrointestinal tract ${ }^{46,47}$.

A study by Wasilewska et al (2003) ${ }^{48}$ developed another selective medium from milk: Raffinose Propionate lithium Mupirocin. In the year 2003, Ewa isolated Bifidobacteria from infant feces by two newly-modified Gerche's media:

1). One with stimulating Bifidobacteria growth maltodextring instead of lactose.

2). Addition of lithium chloride $(3 \mathrm{~g} / \mathrm{L})$ and Penicillin G, Sodium salt (50 U/L).

Culture medium used in different samples for the enumeration of Bifidobacterium $\mathrm{sp}$ is shown in Table 2.

\section{Species of Bifidobacteria}

More than thirty two Bifidobacterium species have been identified by scientists ${ }^{49,50}$. Distribution of principal species of Bifidobacterium is represented in Table 3 and major findings on Bifidobacterium sp in Table 4.

\section{Bifidobacterium Sp in probiotic foods}

Bifidobacterium bifidum grew better in milk under anaerobic conditions than standard strains. This strain gave the best results when it was added at $5-10 \%$ to milk and when stored at $\mathrm{pH}$ 5.0-5.3, and storage at lower $\mathrm{pH}$ adversely affected growth and acid production. Kanbe et al $(2007)^{51}$ reviewed the characteristics of 
Bifidobacterium spp. growth factors and evidence for its beneficial effects on protein metabolism, vitamin metabolism, fecal excretion, kidney problems and the immune response. Fernandes et al (1987) ${ }^{52}$ and Guo et al (2010) ${ }^{53}$ mentioned that Lactobacillus spp. along with $B$. bifidum constituted health benefits. Hughes and Hoover $(2011)^{54}$ discussed Bifidobacteria, a group of lactose-utilizing bacteria, with emphasis on classification. Recent research has focused on these organisms and the benefits obtained from the ingestion of bifid-containing food products. Misra and Kuila (2001) $)^{55}$ summarized the biological activities, the role of Bifidobacteria, preparation and the antimicrobial activity and therapeutic properties of bifidus milk. Consumption of bifidus milk with a high number $(108 \mathrm{cfu} / \mathrm{g})$ of this organism will provide $L(+)$-lactic acid, antibiotic factor and live Bifidobacteria in addition to other nutritional components. The combined action of these factors will create favorable conditions for the proliferation of intestinal Bifidobacteria, and discourage the growth of harmful organisms ${ }^{56}$.

\section{Bifidobacteria and functional foods}

Functional foods are "food containing some health promoting components, also called as super food, designer foods etc., and functional by means of adding probiotics ${ }^{10}$. Certain Lactic acid bacteria including Lactobacillus and Bifidobacterium genus are used as functional ingredients in probiotic food products ${ }^{9}$. Bifidobacterium sp, isolated from different food products, is shown in Table 5 . The main challenge associated with the application of probiotic cultures in functional food is their viability during processing. B. animalis subsp. lactis BB-12 is a widely used probiotic strain in food manufacture because of its viability ${ }^{57}$.

Table 2. Culture medium used in different samples for enumeration of Bifidobacterium sp

\begin{tabular}{llc}
\hline Sample Type & Media Used & Reference \\
\hline Breast milk & MRS supplemented & 35 \\
& with 0.5 g/L L-cysteine HCL & \\
Infant feces & MRS + 0.25 g/L L-cysteine & $1,70,6$ \\
& Bifidobacterium Agar & 2 \\
Dairy products & TPY agar & 71 \\
Milk & MRS broth , & \\
& Bifido selective medium & 72 \\
Animal feed & TOS-Propionate Agar+ Mupirocin & \\
Yogurts & BSM agar, MRS supplemented & 1 \\
Infant gut & Gith cysteine HCL and Mupirocin & 73 \\
\hline
\end{tabular}

Table 3. Distribution of species of Bifidobacterium

\begin{tabular}{|c|c|c|c|c|}
\hline Human Groups & $\begin{array}{l}\text { Rabbit } \\
\text { Species }\end{array}$ & Cow & Swine Faeces & $\begin{array}{l}\text { Honeybee } \\
\text { Species }\end{array}$ \\
\hline B.adolescentis & B.magnum & B.bifidum & B.pseudocatenulatum & B.indicum \\
\hline B.bifidum & B.saeculare & B.breve & B.choerinum & B.coryneforme \\
\hline B.breve & B.cumiculi & B.boum & B.aerophilum & \\
\hline B.angulatum & & B.magnum & B.thermoacidophilum & \\
\hline B.catenulatum & & B.ruminantium & B.thermophilum & \\
\hline B.gallicum & & B.thermophilum & B.suis & \\
\hline $\begin{array}{l}\text { B.pseudo- } \\
\text { catenulatum }\end{array}$ & & B.infantis & & \\
\hline B.longum & & B.pseudolongum & & \\
\hline
\end{tabular}




\section{General features of Bifidobacterial genomes}

The NCBI knowledge base presently holds 254 publicly-out Bifidobacteria ordering sequences, of which Ixi represents a complete ordering sequence. 3 or a lot of complete ordering sequences are Bifidobacterial species, like $B$. animalis, B. adolescentis B. breve, B.bifidum, $B$. longum and $B$. angulatum. The typical size of a Bifidobacterial ordering is $2.2 \mathrm{Mb}$, with appreciable differences in size. For instance, B.indicum LMG11587 has an ordering size 1.73 $\mathrm{Mb}$, whereas B. scardoviiJCM12489 has $3.16 \mathrm{Mb}$. Bifidobacterium orderings generally have $52-58$ RNA genes per genome, except the ordering of B. longum subsp. infantis ATCC15697, which has seventy nine tRNA genes. The amount of rRNA

Table 4. Major Findings on Bifidobacterium species

$\begin{array}{lll}\begin{array}{l}\text { Bifidobacterium Major findings } \\ \text { species }\end{array} & \text { Reference } \\ \end{array}$

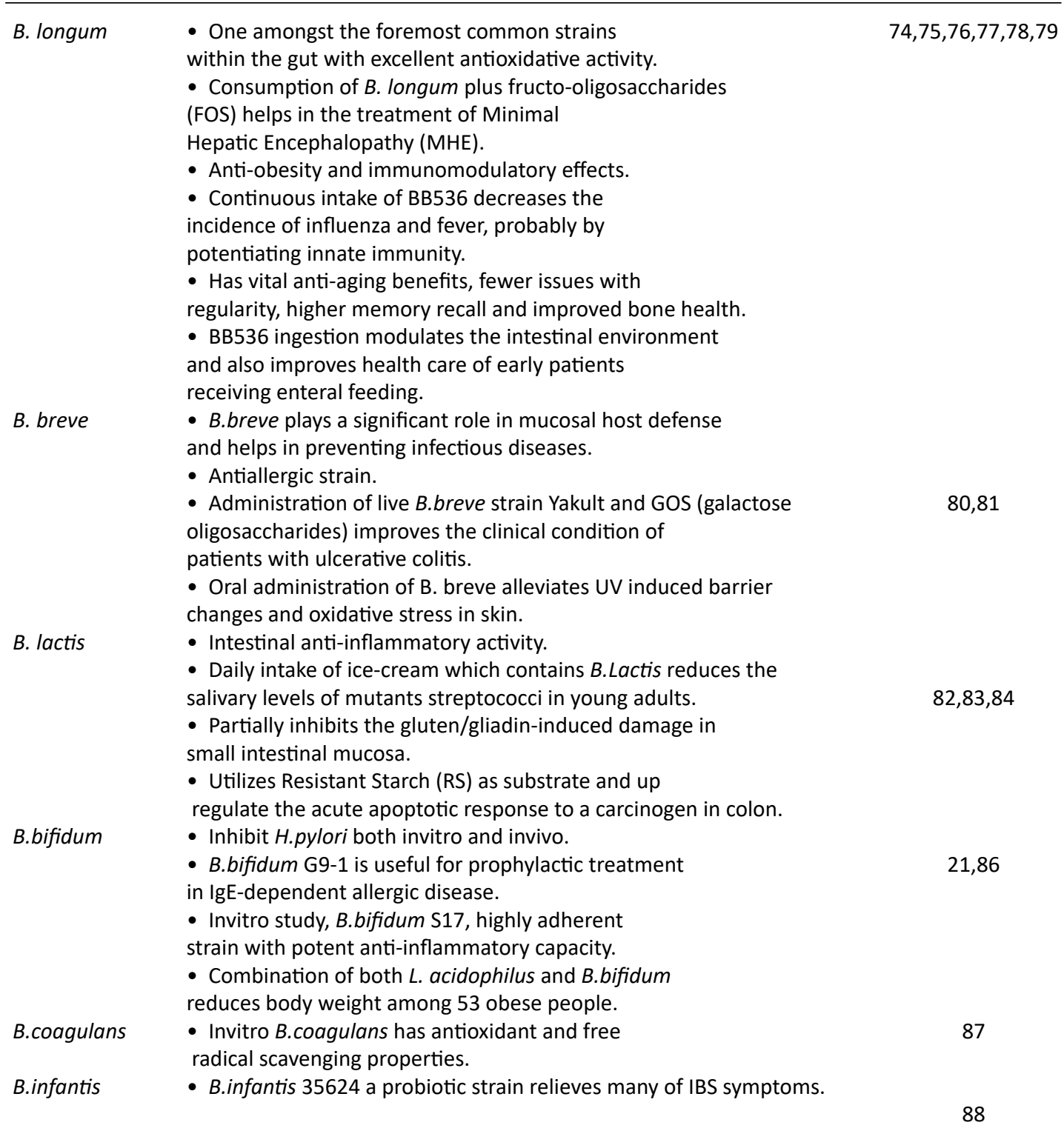


Table 5. Bifidobacterium species isolated from different food products

\begin{tabular}{llc}
\hline Product type & Species isolated & Reference \\
\hline Yogurt & $\begin{array}{l}\text { B.animalis, B.lactis } \\
\text { Butter milk }\end{array}$ & 70 \\
& $\begin{array}{l}\text { B. longum B. B.animalis, } \\
\text { Fermented }\end{array}$ & 89 \\
Soymilk & $\begin{array}{l}\text { B.bifidum B3-12, B.longum Bb-46, B.bifidum B7.1 } \\
\text { and B.breve B9.14 }\end{array}$ & $90,91,92$ \\
Fermented & $\begin{array}{l}\text { B.animalis ssp. lactis BB-12, } \\
\text { B.animalis ssp. animalis }\end{array}$ & 93 \\
milk & & \\
\hline
\end{tabular}

operons among Bifidobacterial genomes generally ranges from 2 to 5 , and it has been recommended that the amount of rRNA operons present on a genome correlate to the variation of a specific species to environmental conditions ${ }^{58,59}$.

\section{CONCLUSION}

The growing attention in each basic analysis and industrial importance of probiotics and the role of Bifidobacterium species is highlighted during this work. Bifidobacteria, as probiotics, may become an important means of reduction of serum cholesterol, alleviation of lactose intolerance, treatment of inflammatory bowel diseases, acute diarrhea, colorectal cancer and other intestinal infections. And these days there is a growing trend in the market for food supported with probiotics. And also it is applied in a variety of products such as powdered health food and medicines, tablets, capsules etc. Most of the Bifidobacterium species currently being studied and in use appear to be safe, with no adverse effects on health. However, it is safe to conclude that Bifidobacterium species holds a great potential as probiotics.

\section{ACKNOWLEDGMENTS}

The authors would like to extend sincere gratitude to the management authorities of Karpagam Academy of Higher Education, Coimbatore, for their constant encouragement and support.

\section{CONFLICT OF INTEREST}

The authors declares that there is no conflict of interest.

\section{AUTHORS' CONTRIBUTION}

All authors have made substantial, direct and intellectual contribution to the work and approved it for publication.

\section{FUNDING}

None.

\section{DATA AVAILABILITY}

All datasets generated or analysed during this study are included in the manuscript.

\section{ETHICAL STATEMENT}

This article does not contain any studies with human participants or animals performed by any of the authors.

\section{REFERENCES}

1. Zinedine A, Faid M . Isolation and characterization of strains of Bifidobacteria with probiotic proprieties in vitro. World J Dairy Food Sci., 2007; 2(1): 28-34.

2. Vlkova E, Rada V, Bujעבkov, D, Kme V. Enumeration, isolation, and identification of bifidobacteria from infant feces. Folia Microbiol., 2004; 49(2): 209-212. https://doi.org/10.1007/BF02931404.

3. Biavati B, Vescovo M, Torriani S, Bottazzi V. Bifidobacteria: history, ecology, physiology and applications. Ann. microbial., 2000; 50(2): 117-132.

4. Pereira D, Gibson G. Cholesterol Assimilation by Lactic Acid Bacteria and Bifidobacteria Isolated from the Human Gut. Appl Environ Microbiol. 2002; 68(9): 4689-4693. https://doi.org/10.1128/AEM.68.9.4689-4693.2002.

5. Sanchez JC, Ruiz L, van Sinderen D, Margolles A, Zomer A. Acid and Bile Resistance and Stress Response in Bifidobacteria, in: Bifidobacteria Genomic and Molecular Aspects. 2010; 69-95.

6. Shivaprakash M, Madhavi G, Chathyushya K, Sumalata $\mathrm{G}$, Kumar S, Hemalatha R. Studies on the identification of Bifidobacteria isolated from Human Breast milk of Indian women. Int. J. Adv. Res., 2017; 5(5):849-856. https://doi.org/10.21474/IJAR01/4187. 
7. Picard C, Fioramonti J, Francois A, Robinson T, Neant F, Matuchansky C. Bifidobacteria as probiotic agentsphysiological effects and clinical benefits. Aliment. Pharmacol. Ther., 2005; 22(6): 495-512. https://doi.org/10.1111/j.1365-2036.2005.02615.x.

8. Pompei A, Cordisco L, Amaretti A, Zanoni S, Matteuzzi $D$, Rossi M . Folate production by bifidobacteria as a potential probiotic property. Appl Environ Microbiol. 2007; 73: 179-185. https://doi.org/10.1128/ AEM.01763-06.

9. Ouwehand AC, Salminen S, \& Isolauri EM . Probiotics: an overview of beneficial effects. Antonie van Leeuwenhoek. 2002; 82, 279-289. https://doi. org/10.1007/978-94-017-2029-8_18.

10. FAO/WHO, Human Vitamin and Mineral Requirements, 2002.

11. Soccol CR, Vandenberghe LP de S, Spier MR, Medeiros $\mathrm{ABP}$, Yamaguishi $\mathrm{CT}$, Lindner, J de D, Pandey, Ashok, Thomaz-Soccol V, Pandey A, Larroche C. The potential of probiotics: a review. Food Technol Biotechnol. 2010; 48: 413-434.

12. Dash SK. Selection criteria for probiotics. Indian Dairyman, 2009; 61(3): 69-73.

13. Daliri, E. B. M., Lee, B. H., \& Oh, D. H. Safety of Probiotics in Health and Disease. In The Role of Functional Food Security in Global Health (pp. 603622). Academic Press, 2019. https://doi.org/10.1016/ B978-0-12-813148-0.00034-7.

14. Verruck, S., \& Prudencio, E. S. Survival of Bifidobacterium ssp. during gastrointestinal passage and their mechanism of action for pathogenic bacteria inhibition in the gut: a concise review. Food Biology, 2019; 01-06. https://doi.org/10.25081/fb.2019.v8.3856.

15. Yaeshima T, Takahashi $\mathrm{S}$, Matsumoto N, Ishibashi N, Hayasawa $\mathrm{H}$, lino $\mathrm{H}$. Effect of yogurt containing $B$. longum BB536 yogurt on the intestinal environment, fecal characteristics and defecation frequency. Biosci Microflora., 1997; 16: 73-77. https://doi. org/10.12938/bifidus1996.16.73.

16. Mitsuoka T. Taxonomy and ecology of bifidobacteria. Bifidobacteria and Micro flora. 1984; 3(1): 11-28. https://doi.org/10.12938/bifidus1982.3.1_11.

17. Parvez $S$, Malik . Probiotics and their fermented food products are beneficial for health. Appl. Micro., 2006; 100(1171-1185). https://doi.org/10.1111/j.13652672.2006.02963.x.

18. Rossi M, Amaretti A, Roncaglia L, Leonardi A, Raimondi S. Dietary Isoflavones and Intestinal Microbiota: Metabolism and Transformation into Bioactive Compounds, in: Thompson, M.J. Isoflavones Biosynthesis. Occurrence and Health Effects., 2010; 137-161.

19. Usha, V, Pradeep B.V. Isolation, identification and characterization of a novel probiotic strain (lactobacillus paracasei kumbb005) from cow milk samples and its antibacterial activity. World J. Pharma. Res., 2014; 3(5):599-612.

20. El-Shafie, HA, Yahia NI, Ali HA, Khalil FA, El-Kady EM, Moustafa YA. Hypocholesterolemic action of Lactobacillus plantarum NRRL-B-4524 and Lactobacillus paracasei in mice with hypercholesterolemia induced by diet. Aus. J. Basic Appl. Sci., 2009; (3): 218-228.
21. Chenoll E, Casinos B, Bataller E, Astals P, Echevarr Da J, Iglesias JR, Genov's S. Novel probiotic Bifidobacterium bifidum CECT 7366 strain active against the pathogenic bacterium Helicobacter pylori. App. EnvironMicrobiol., 2011; 77(4): 1335-1343. https://doi.org/10.1128/AEM.01820-10.

22. Sen, $M$. Role of Probiotics in Health and Disease-A Review. Int. J. Advance Life Sci. Resea., 2019; 1-11. https://doi.org/10.31632/ijalsr.2019v02i02.001.

23. Song, H., Kim, J., Jung, S., Kim, S., Park, H., \& Jeong. Effect of Probiotic Lactobacillus (Lacidofil ${ }^{\circledR}$ Cap) for the Prevention of Antibiotic-associated Diarrhea: A Prospective, Randomized, Double-blind, Multicenter Study. J. Korean Med. Sci., 2010; 25(12): 1784.

24. O'Callaghan A and van Sinderen D. Bifidobacteria and Their Role as Members of the Human Gut Microbiota. Front Microbiol., 2016; 7: 925. https://doi.org/10.3389/fmicb.2016.00925.

25. Fotiadis $\mathrm{Cl}$, Stoidis CN, Spyropoulos BG, Zografos ED. Role of probiotics, prebiotics and synbiotics in chemoprevention for colorectal cancer. World J. Gastroenterol., 2008; 14(42): 6453. https://doi.org/10.3748/wjg.14.6453.

26. Gueimonde M, Ouwehand A, Huhtinen $\mathrm{H}$, Salminen E, Salminen $S$. Qualitative and quantitative analyses of the bifidobacterial microbiota in the colonic mucosa of patients with colorectal cancer, diverticulitis and inflammatory bowel disease. World J. Gastroenterol., 2007; 13(29): 3985

27. Winkler P, Ghadimi D, Schrezenmeir J \& Kraehenbuhl JP. Molecular and cellular basis of microflora-host interactions. J. Nutr. 2007; 137(3): 7565-772S. https://doi.org/10.1093/jn/137.3.756S.

28. Spacova, I., Ceuppens, J. L., Seys, S. F., Petrova, M. I., \& Lebeer, S. Probiotics against airway allergy: host factors to consider. Disease models \& mechanisms., 2018; 11(7): 034314. https://doi.org/10.1242/dmm.034314.

29. Ren, J., Zhao, Y., Huang, S., Lv, D., Yang, F., Lou, L., ... \& Bachert, C. . Immunomodulatory effect of Bifidobacterium breve on experimental allergic rhinitis in BALB/c mice. Experimental and therapeutic medicine., 2018; 16(5): 3996-4004. https://doi. org/10.3892/etm.2018.6704.

30. Fu, L., Cherayil, B. J., Shi, H., Wang, Y., \& Zhu, Y. Food Allergy and the Microbiota: Implications for Probiotic Use in Regulating Allergic Responses. In Food Allergy, 2019; 179-194). https://doi.org/10.1007/978-981-136928-5_8.

31. Yousefi, B., Eslami, M., Ghasemian, A., Kokhaei, P., Salek Farrokhi, A., \& Darabi, N.. Probiotics importance and their immunomodulatory properties. Journal of cellular physiology, 2019; 234(6): 8008-8018. https:// doi.org/10.1002/jcp.27559.

32. Saab, S., Suraweera, D., Au, J., Saab, E., Alper, T., \& Tong, M. Probiotics are helpful in hepatic encephalopathy: a meta-analysis of randomized trials. Liver International, 2015; 36(7): 986-993. https://doi.org/10.1111/ liv.13005.

33. Adawi D, Ahrne S, Molin G: Effects of different probiotic strains of Lactobacillus and Bifidobacterium on bacterial translocation and liver injury in an acute liver injury model. Int. J. Food Microbiol., 2001; 70: 213. 
https://doi.org/10.1016/S0168-1605(01)00550-5.

34. Kirpich IA, Solovieva NV, Leikhter SN, Shidakova NA, Lebedeva OV, Sidorov PI, Bazhukova TA, Soloviev AG, Barve SS, McClain CJ, Cave M. Probiotics restore bowel flora and improve liver enzymes in human alcohol-induced liver injury: a pilot study. Alcohol., 2008; 42: 675-682. https://doi.org/10.1016/j. alcohol.2008.08.006.

35. Dheyaa MN, Mohammed AJ, Abdallah KH. Phenotypic and Molecular identification of Bifidobacterium sp. Isolated from Infant feces. J. Pure Appl. sci., 2016 ;3: 24.

36. Sghir A, Gramet G, Suau A, Rochet V, Pochart P, Dore J . Quantification of Bacterial Groups within Human Fecal Flora by Oligonucleotide Probe Hybridization. Appl. Environ. Microbiol., 2000; 66(5): 2263-2266. https://doi.org/10.1128/AEM.66.5.2263-2266.2000.

37. Atassi F, Servin AL. Individual and co-operative roles of lactic acid and hydrogen peroxide in the killing activity of enteric strain Lactobacillus johnsonii NCC933 and vaginal strain Lactobacillus gasseri KS120.1 against enteric, uropathogenic and vaginosis-associated pathogens. FEMS Microbiol. Lett., 2010; 304: 29-38. https://doi.org/10.1111/j.1574-6968.2009.01887.x.

38. Dobson, A., Cotter, P. D., Ross, R. P., \& Hill, C. Bacteriocin production: a probiotic trait?. Appl. Environ. Microbiol., 2012; 78(1): 1-6. https://doi.org/10.1128/AEM.0557611.

39. Shah NP \& Dave R .Antimicrobial substances including bacteriocins produced by lactic acid bacteria. Biosci Microflora., 2002; 21(4): 217-223. https://doi.org/10.12938/bifidus1996.21.217.

40. Sarkar A \& Mandal S. Bifidobacteria-Insight into clinical outcomes and mechanisms of its probiotic action. Microbiol. Res., 2016; 192: 159-171. https://doi.org/10.1016/j.micres.2016.07.001.

41. Gopal PK, Prasad J, Smart J \& Gill HS . In vitro adherence properties of Lactobacillus rhamnosus DR20 and Bifidobacterium lactis DR10 strains and their antagonistic activity against an enterotoxigenic Escherichia coli. Int. J. Food Microbiol., 2001; 67(3): 207-216. https://doi.org/10.1016/\$0168-1605(01)00440-8.

42. Ruas-Madiedo $P$, Gueimonde M, Fernandez-Garc|" 'a M, Clara G, Margolles A. Mucin degradation by Bifidobacterium strains isolated from the human intestinal microbiota. Appl. Environ. Microbiol., 2008; 74(6):193640. https://doi.org/10.1128/AEM.0250907.

43. Brigidi P, Vitali B, Swennen E, Bazzocchi G, Matteuzzi D Effects of probiotic administration upon the composition and enzymatic activity of human fecal microbiota in patients with irritable bowel syndrome or functional diarrhea. Res. microbial., 2001; 152(8): 735-741. https://doi.org/10.1016/S0923-2508(01)01254-2.

44. Odooli S A, Safari M, Kargar Y, Ghasemi. Selection detection, isolation, and enumeration of Bifidobacterium animalis subsp. lactis BB-12 from Iranian commercial probiotic yoghurts. Trends Pharma. Sci., 2016; 2(4).

45. Roy $D$. Media for the isolation and enumeration of bifidobacteria in dairy products. Int. J. Food Microbiol., 2001; 69(3): 167-182. https://doi.org/10.1016/S0168-
1605(01)00496-2.

46. Rada V, Petr J. A new selective medium for the isolation of glucose non-fermenting bifidobacteria from hen caeca. J. Microbiol. Methods., 2000; 43(2): 127-132. https://doi.org/10.1016/S0167-7012(00)00205-0.

47. Thitaram S, Siragusa G, Hinton A . Bifidobacteriumselective isolation and enumeration from chicken caeca by a modified oligosaccharide antibiotic-selective agar medium. Lett. Appl. Microbiol., 2005; 41(4): 355-360. https://doi.org/10.1111/j.1472-765X.2005.01765.x.

48. Wasilewska $\mathrm{E}$, Bielecka M . Isolation and identification of bifidobacteria from infant gut. Pol. J. Food Nutr. Sci., 2003; 12: 90-94.

49. Zhu L, Li W, Dong X. Species identification of genus Bifidobacterium based on partial HSP60 gene sequences and proposal of Bifidobacterium thermoacidophilum subsp. porcinum subsp. nov. Int. J. Sys. Evol. Microbiol., 2003; 53(5): 1619-1623. https://doi.org/10.1099/ijs.0.02617-0.

50. Requena T, Burton J, Matsuki T, Munro K, Simon MA, Tanaka R, Tannock GW . Identification, detection, and enumeration of human Bifidobacterium species by PCR targeting the transaldolase gene. Appl. Environ. Microbiol., 2002; 68(5): 2420-2427. https://doi.org/10.1128/AEM.68.5.2420-2427.2002.

51. Kanbe $M$. Health and the utilization of intestinal lactic acid bacteria. New Food Industry, 2007; 28(8): 41-51.

52. Fernandes C.F, Shahani KM, Amer MA. Therapeutic role of dietary lactobacilli and Lactobacilli fermented dairy products. FEMS Microbiol Rev., 1987; 46(3): 343-356. https://doi.org/10.1016/0378-1097(87)90118-2.

53. Guo C, Zhang L. Cholesterol-lowering effects of probiotics-a review. Acta microbial Sin., 2010; 50(12): 1590-1599.

54. Hougee $\mathrm{S}$, Vriesema A, Wijering S, Knippels L, Folkerts G, Nijkamp F.et al. (2010). Oral Treatment with Probiotics Reduces Allergic Symptoms in OvalbuminSensitized Mice: A Bacterial Strain Comparative Study. Int. Arch. Allergy Immunol., 151(2): 107-117. https://doi.org/10.1159/000236000.

55. Misra AK, RK Kuila. Bifidus milk: potential for developing countries. Indian Dairyman., 2001; 43(9): 390-393.

56. Ishibashi N, Yaeshima $T$ \& Hayasawa $H$. Bifidobacteria: their significance in human intestinal health. Malays J. Nutr., 1997; 3(2): 149-159.

57. Jungersen $M$, Wind $A$, Johansen $E$, Christensen $J E$, Stuer-Lauridsen B, Eskesen D. The science behind the probiotic strain Bifidobacterium animalis subsp. lactis BB-12. Microorganisms, 2014; 2(2): 92-110. https://doi.org/10.3390/microorganisms2020092.

58. Oelschlaeger TA .Mechanisms of probiotic actions -A review. Int. J. Med. Microbiol. 2010; 300: 57-6. https://doi.org/10.1016/j.ijmm.2009.08.005.

59. Collado MC, Delgado S, Maldonado A, Rodroguez JM . Assessment of the bacterial diversity of breast milk of healthy women by quantitative real time PCR. Lett. Appl. Microbiol. 2009; 48(5): 523-528. https://doi.org/10.1111/j.1472-765X.2009.02567.x.

60. Raghuwanshi S, Misra S, Sharma R, Bisen P S . Probiotics: Nutritional Therapeutic Tool. J. Prob. Health, 2018; 6(194): 2. https://doi.org/10.4172/2329- 


\subsection{4.}

61. Ugidos-Rodroguez S, Matallana-Gonzzlez MC, SבnchezMata MC. Lactose malabsorption and intolerance: a review. Food Function, 2018; 9(8): 4056-4068. https://doi.org/10.1039/C8FO00555A.

62. Deng Y, Misselwitz B, Dai N, Fox M .Lactose intolerance in adults: biological mechanism and dietary management. Nutrients, 2015; 7(9): 8020-8035. https://doi.org/10.3390/nu7095380.

63. Applegate J A, Walker C LF, Ambikapathi, R, Black RE Systematic review of probiotics for the treatment of community-acquired acute diarrhea in children. $B M C$ public health, 2013; 13(3): S16.

64. Fijan S. Microorganisms with Claimed Probiotic Properties: An Overview of Recent Literature. Int. J. Environ. Res. Public Health, 2014; 11(5): 4745-4767. https://doi.org/10.3390/ijerph110504745.

65. Mogna G, Strozzi GP, Mogna L, U.S. Patent No. 9,925,224. Washington, DC: U.S. Patent and Trademark Office, 2018.

66. Thibault $\mathrm{H}$ \& Aubert-Jacquin C. Effects of long-term consumption of a fermented infant formula on acute diarrhea in healthy infants. J. Pedia Gastro Nutri., 2004; 39(1): S548. https://doi.org/10.1097/00005176200406001-01411.

67. Geier MS, Butler RN, Howarth GS. Probiotics, prebiotics and synbiotics: a role in chemoprevention for colorectal cancer. Cancer Biol. Ther., 2006; 5(10): 1265-1269. https://doi.org/10.4161/cbt.5.10.3296.

68. Gionchetti, P., Rizzello, F., Morselli, C., Poggioli, G., Tambasco, R., \& Calabrese. . High-dose probiotics for the treatment of active pouchitis. Dis of The Colon Rectum., 2006; 50(12): 2075-2084. https://doi. org/10.1007/s10350-007-9068-4.

69. Rani VU \& Pradeep BV. Application of Anticancer Agents from Fermentation of Soy Using Bifidobacterium and Lactobacillus spp. A Review. Academic J. Cancer Res., 2014; 7(3): 185-192.

70. Hadadji M, Benama R, Saidi N, Henni DE, Kihal M. Identification of cultivable Bifidobacterium species isolated from breast-fed infants feces in WestAlgeria. African J. Biotechnol., 2005; 4(5): 422-430.

71. Tu ar T, erdoner K, Bogoviu Matija ir B, Pavelj ek D, Benedik E, Brataniv B, Rogelj I. Cultivable Bacteria from Milk from Slovenian Breastfeeding Mothers. Food Technol Biotechnol., 2014; 52(2).

72. Simpson P, Fitzgerald G, Stanton C, Ross R. The evaluation of a mupirocin-based selective medium for the enumeration of bifidobacteria from probiotic animal feed. J. Microbiol. Methods, 2004; 57(1): 9-16. https://doi.org/10.1016/j.mimet.2003.11.010.

73. Wasilewski A, Zielioska M, Storr M, Fichna J . Beneficial Effects of Probiotics, Prebiotics, Synbiotics, and Psychobiotics in Inflammatory Bowel Disease. Inflammatory Bowel Diseases, 2015; 21(7):1674-1682. https://doi.org/10.1097/ MIB. 0000000000000364 .

74. Lin MY, Chang FJ . Antioxidative effect of intestinal bacteria Bifidobacterium longum ATCC 15708 and Lactobacillus acidophilus ATCC 4356. Dig. Dis. Sci., 2000; 45(8): 1617-1622.

75. Malaguarnera M, Greco F, Barone G, Gargante MP,
Malaguarnera M, Toscano MA. Bifidobacterium longum with fructo-oligosaccharide (FOS) treatment in minimal hepatic encephalopathy: a randomized, double-blind, placebo-controlled study. Digest Dis Sci., 2007; 52(11): 3259. https://doi.org/10.1007/s10620-006-9687-y.

76. Pandey KR, Naik SR, Vakil B V. Probiotics, prebiotics and synbiotics-a review. J. food Sci. Technol., 2015; 52(12): 7577-7587. https://doi.org/10.1007/ s13197-015-1921-1.

77. Namba K., Hatano M, Yaeshima T, Takase M, Suzuki K . Effects of Bifidobacterium longum BB536 administration on influenza infection, influenza vaccine antibody titer, and cell-mediated immunity in the elderly. Biosci. Biotechnol. Biochem., 2010; 74(5): 939-945. https://doi.org/10.1271/bbb.90749.

78. Biagi E, Candela M, Fairweather-Tait S, Franceschi C, Brigidi $P$. Ageing of the human metaorganism: the microbial counterpart. Age., 2012; 34(1): 247-267. https://doi.org/10.1007/s11357-011-9217-5.

79. Kondo J, Xiao JZ, Shirahata A, Baba M, Abe A, Ogawa $K$, Shimoda, T. Modulatory effects of Bifidobacterium longum BB536 on defecation in elderly patients receiving enteral feeding. World J. Gastroenterol., 2013; 19(14): 2162. https://doi.org/10.3748/wjg.v19. i14.2162.

80. Ishibashi N, Yamazaki S. Probiotics and safety. Am J Clin Nutr., 2001; 73(2): 465-470. https://doi.org/10.1093/ ajcn/73.2.465s.

81. Ishii Y, Sugimoto S, Izawa N, Sone T, Chiba K., Miyazaki $\mathrm{K}$. Oral administration of Bifidobacterium breve attenuates UV-induced barrier perturbation and oxidative stress in hairless mice skin. Arch Dermatol Res., 2014; 306(5): 467-473. https://doi.org/10.1007/ s00403-014-1441-2.

82. Imaoka, A, Shima T, Kato K, Mizuno S, Uehara T, Matsumoto S, Umesaki Y. Anti-inflammatory activity of probiotic Bifidobacterium: enhancement of IL-10 production in peripheral blood mononuclear cells from ulcerative colitis patients and inhibition of IL-8 secretion in HT-29 cells. World J. Gastroenterol., 2008; 14(16): 2511. https://doi.org/10.3748/wjg.14.2511.

83. Caglar E, Onder Kuscu O, Selvi Kuvvetli S, Kavaloglu Cildir S, Sandalli N, Twetman S. Short-term effect of ice-cream containing Bifidobacterium lactis $\mathrm{Bb}-12$ on the number of salivary mutants Streptococci and Lactobacilli. Acta Odontol Scand., 2008; 66(3): 154-158. https://doi.org/10.1080/00016350802089467.

84. Lindfors K, Blomqvist T, Juuti Uusitalo K, Stenman $\mathrm{S}$, Venהlininen J, Mnki M, Kaukinen K. Live probiotic Bifidobacterium lactis bacteria inhibit the toxic effects induced by wheat gliadin in epithelial cell culture. Clin Exp Immunol., 2008; 152(3): 552-558. https://doi.org/10.1111/j.1365-2249.2008.03635.x.

85. Le Leu, RK, Brown IL, Hu Y, Bird AR, Jackson M, Esterman A, Young, GP. A synbiotic combination of resistant starch and Bifidobacterium lactis facilitates apoptotic deletion of carcinogen-damaged cells in rat colon. J. Nutr., 2005; 135(5): 996-1001. https://doi.org/10.1093/jn/135.5.996.

86. Mikirova N, Casciari J, Hunninghake R, Beezley M . Effect of Weight Reduction on Cardiovascular 
Risk Factors and CD34-positive Cells in Circulation. Int. J. Med Sci., 2011; 8(6): 445-452. https://doi.org/10.7150/ijms.8.445.

87. Kishk $\mathrm{Y}, \mathrm{Al}$-Sayed $\mathrm{H}$. Free-radical scavenging and antioxidative activities of some polysaccharides in emulsions. LWT-Food Sci. Technol., 2007; 40(2):270-277. https://doi.org/10.1016/j.Iwt.2005.11.004.

88. E Wasilewska And Bielecha M. Isolation and identification of Bifidobacteria from infant gut. J. Food Nutr. Sci., 2003; 12(53).

89. Antunes A, Grael E, Moreno I, Rodrigues L, Dourado, F, Saccaro D, Lerayer A (2007) Selective enumeration and viability of Bifidobacterium animalis subsp. lactis in a new fermented milk product. Braz. J. Microbiol., 2007; 38(1):173-177. https://doi.org/10.1590/S1517-83822007000100035.

90. Havas P, Kun S, Perger-M'szבros I, Rezessy-Szabๆ JM,
Nguyen QD (2015) Performances of new isolates of Bifidobacterium on fermentation of soymilk. Acta microbial Immunol. Hung., 2015; 62(4): 463-475. https://doi.org/10.1556/030.62.2015.4.10.

91. Chou CC, Hou JW. Growth of bifidobacteria in soymilk and their survival in the fermented soymilk drink during storage. Int. J. Food Microbiol., 2000; 56(3):113-121. https://doi.org/10.1016/S0168-1605(99)00201-9.

92. Bozanic R, Lovkovic S, Jelicic I. Optimizing fermentation of soymilk with probiotic bacteria. Czech J. Food Sci., 2011; 29(1): 51-56. https://doi.org/10.17221/97/2010-CJFS.

93. Plessas S, Bosnea L, Alexopoulos A, Bezirtzoglou E. Potential effects of probiotics in cheese and yogurt production: A review. Eng Life Sci., 2012; 12(4): 433-440. https://doi.org/10.1002/elsc.201100122. 